\title{
POR QUE A TEORIA DA TRADUÇÃO É ÚTIL PARA OS TRADUTORES? ${ }^{1}$
}

\author{
José Antonio Sabio Pinilla 1 \\ 1 Universidade de Granada \\ Tradução de Willian Henrique Cândido Moura² \\ Morgana Aparecida de Matos 2 \\ Fernanda Christmann² \\ ²Universidade Federal de Santa Catarina, Florianópolis, Santa Catarina, Brasil
}

\begin{abstract}
Resumo: Este artigo levanta a questão da utilidade da teoria da tradução para a atividade prática dos tradutores. A utilidade da teoria é certamente um tema controverso que levou a um intenso debate entre os especialistas. Embora existam escolas e faculdades onde os estudos da Tradução e Interpretação são ministrados há mais de trinta anos, a teoria ainda provoca desconfiança não só entre os tradutores que não estudaram Tradução, mas também entre os estudantes e até entre os professores. Tal fato não deixa de surpreender se pensarmos que a teoria, entendida em sentido amplo, é parte essencial dos estudos superiores e está na base da nossa disciplina. Partindo de algumas leituras e da minha experiência como professor de Tradutologia na Universidade de Granada, pretendo responder à pergunta do título e a outras questões a ela relacionadas como: de qual teoria o tradutor precisa?, quais as relações entre teoria e prática da tradução? E para que serve a teoria da tradução?
\end{abstract}

Palavras-chave: Teoria da Tradução; Prática da Tradução; Tradução Profissional; Formação de Tradutores; Utilidade

${ }^{1}$ Este artigo foi publicado inicialmente na Revista Conexão Letras, v.12, n.17, em agosto de 2017, sob o título: ¿Por qué es útil la teoría de la traducción para los traductores? A tradução do artigo para a língua portuguesa ocorreu mediante a autorização prévia do autor, o qual recebe nossos mais profundos agradecimentos. Mesmo que alguns dos trabalhos aqui citados possuam traduções oficiais na língua portuguesa, todas as citações presentes neste artigo foram traduzidas, do artigo original, pelos tradutores. 


\title{
WHY IS THE TRANSLATION THEORY USEFUL FOR TRANSLATORS?
}

\begin{abstract}
This paper presents the usefulness of translation theory for translators. It is an undoubtedly controversial subject that has given rise to intense debates among specialists. Despite the existence of schools and colleges where translation and interpretation studies have been carried out, for over thirty years, the theory still incites doubts, not only among translators who did not study Translation but also between students and even teachers. This fact is not surprising if we think that the theory, understood in a general sense, is an essential part of university studies and supports the subject itself. Based on some readings and also in my experience as a teacher of Traductología at the University of Granada, I intend to answer the question of the title and some additional issues such as: What kind of theory needs a translator? What relations exist between the theory and the practice of translation? What is the use of the theory of translation?
\end{abstract}

Keywords: Theory of Translation; The Practice of Translation; Professional Translation; Training of Translators; Utility

\section{Introdução}

O título deste trabalho, que parafraseia o título de um artigo de Venuti, problematiza a utilidade da teoria da tradução para os tradutores. Trata-se, sem dúvida, de uma questão controversa que gerou intensos debates entre especialistas. De minha parte, considero a teoria da tradução útil porque fornece ferramentas que servirão à vida profissional do tradutor e do estudante de tradução. Ao longo da história, a grande maioria dos tradutores se dedicou apenas à tradução, sem se preocupar com a maneira como a faziam e, quando refletiram, realizaram-na de modo pontual, a partir de sua prática. Isso tem sido uma constante até os dias atuais. Estas reflexões, provenientes da prática, não constituem, estritamente, uma teoria, mas nos orientam sobre o tipo de questionamentos e de problemas que preocupam os tradutores. Por sua vez, a institucionalização dos Estudos da Tradução, durante a segunda metade do 
século XX, resultou no nascimento de teorias modernas de tradução que obedecem a uma necessidade de pesquisa no âmbito acadêmico e visam, primordialmente, a formação de tradutores. Embora existam escolas e universidades onde os Estudos da Tradução e da Interpretação são ministrados há mais de trinta anos, a teoria ainda provoca desconfiança, não só entre os tradutores que não estudaram Tradução, mas também entre os estudantes e, inclusive, entre os professores. Esse fenômeno não deixa de ser paradoxal se pensarmos que a teoria, entendida em sentido amplo, é a que sustenta os estudos universitários e define o que é uma disciplina. Certamente, há tradutores que traduzem sem saber nada sobre teoria da tradução e também há teóricos que teorizam sobre a tradução sem nada terem traduzido (Peña 53), mas essas são atitudes pouco recomendáveis. A partir de algumas leituras e de minha experiência como professor da disciplina de Tradutologia na Universidade de Granada, tentarei matizar, nas páginas a seguir, estes pontos de vista para responder à pergunta do título, que inclui outras como: de qual teoria o tradutor precisa?; por que a teoria desperta tanto receio entre os tradutores e especialistas?; que relações existem entre a teoria e a prática da tradução?; e, finalmente, para que serve a teoria da tradução?

\section{Das primeiras reflexões sobre a tradução até os Estudos da Tradução}

O começo da reflexão sobre a tradução se situa no mundo ocidental em meados do século I a.C. com o prólogo De optimo genere oratorum (ca. 46 a.C.) de Cícero, que precede à versão latina de dois discursos de Esquines e Demóstenes. Durante séculos, as reflexões sobre a tradução se procederam, principalmente, da prática dos tradutores. Pode-se dizer que a teoria esteve marcada pelo caráter empírico da atividade, produto da tradução de textos clássicos, da Bíblia e de obras literárias, embora também possa ter sido disseminada por uma variedade de obras de diversos teores, cuja

Cad. Trad., Florianópolis, v. 39, no 3, p. 595-621, set-dez, 2019. 
elaboração obedeceu a condições culturais, históricas e ideológicas muito particulares. Essa quantidade de reflexões, que não constituem propriamente "uma teoria", contém a base das respostas a muitas das perguntas que ainda permanecem na atualidade. Ao mesmo tempo, durante esta etapa "pré-científica" da teoria, podemos encontrar uma certa sistematização em obras que hoje em dia são consideradas precursoras, tais como o tratado De interpretatione recta, de Leonardo Bruni (ca. 1420), o método Règles de la traduction, de Gaspar de Tende (1660), o Essay on the Principles of Translation, de Alexander Fraser Tytler (1792), ou a conferência Über die verschiedenen Methoden des Übersetzens (Sobre os diferentes métodos de traduzir) de Friedrich Schleiermacher (1813), em que esta última figura como uma aproximação entre hermenêutica e tradução, com influência decisiva nas ideias de Walter Benjamin ou José Ortega y Gasset. Segundo Franco Aixelá (157a), quatro eixos prescritivistas marcaram a reflexão no estado "précientífico" da teoria da tradução: sua visão da linguagem como um meio de rotular realidades idênticas, seu caráter prático, sua obsessão pela Bíblia e pelos clássicos e, por último, sua inclinação pela tradução literal e livre ou entre palavra e sentido. Cabe ao historiador da tradução trazer à tona toda essa atividade, estudá-la, estabelecer relações e apresentar uma estrutura, como uma história, em que o passado se integre à disciplina e seja útil para o presente.

No entanto, será a partir da segunda metade do século XX quando, propiciadas por fatores como o aumento das relações internacionais ou o desenvolvimento tecnológico e a institucionalização progressiva da tradução como área de conhecimento na universidade, começam a surgir reflexões sobre a tradução, provenientes da área acadêmica. Nestas primeiras manifestações teóricas, surgidas entre os anos cinquenta e setenta do século XX, reivindicava-se uma aproximação mais sistemática e analítica para a tradução, considerada até então como uma atividade subsidiária, adscrita a outras áreas de conhecimento como a linguística, a literatura ou o ensino de línguas. Estas primeiras contribuições constituem, nas palavras de Vega (53), a “etapa de fundação da teoria da tradução moder- 
na”, pois representam as primeiras tentativas de sistematização do estudo da tradução. Esta etapa se caracteriza pelo protagonismo da perspectiva linguística, em que a tradução é concebida como uma operação de translação realizada entre dois sistemas linguísticos e a ênfase é colocada na análise contrastiva das línguas. Nesta etapa, também aparece elaborado de forma mais explícita o conceito de "equivalência", que é, sem dúvida, um dos conceitos que mais marcaram a reflexão tradutológica até nossos dias. Como autores representativos desta "primeira geração de tradutólogos" (Hurtado Albir 26a) poderíamos destacar Fedorov, Cary, Vinay e Darbelnet, Jakobson, Mounin, Catford e Nida and Taber.

Na década de setenta, mais especificamente em 1972, Holmes apresenta The Name and Nature of Translation Studies, ${ }^{2}$ que constitui a primeira tentativa de definição do que atualmente se consideram os Estudos da Tradução, além de ser considerado como o trabalho fundador da disciplina (Gentzler 92). Neste trabalho, além de propor a denominação Estudos da Tradução ${ }^{3}$, Holmes desenhou um mapa ou esquema da composição da disciplina, o qual modificou em ocasiões posteriores (Toury a; b; Hurtado Albir a; Vandepitte) e que continua sendo uma referência indispensável. A partir do trabalho de Holmes, os Estudos da Tradução começam a ser considerados como uma disciplina autônoma que dá seus primeiros passos durante os anos setenta, época caracterizada pela "reivindicação da tradução como atividade textual (e não centrada apenas no plano da língua)" (Hurtado Albir 127b), e em que os esforços se dirigem à elaboração de uma teoria da tradução sendo "uma teoria

2 Comunicação apresentada no III Congresso Internacional de Linguística Aplicada, Copenhague, 21 a 26 de agosto de 1972.

3 Atualmente coexistem diversos termos para denominar a disciplina. Em inglês encontramos expressões como: Translation Studies, Science of Translation, Translation Theory; em francês temos Traductologie, Théorie de la traduction; em alemão Übersetzungstheorie, Übersetzungswissenchaft; em espanhol Estudios de Traducción, Estudios sobre la Traducción, Traductología, Teoría de la Traducción e em português Estudos de Tradução, Estudos da Tradução, Teoria da Tradução, Tradutologia, para citar somente as denominações mais frequentes.

Cad. Trad., Florianópolis, v. 39, no 3, p. 595-621, set-dez, 2019. 
compreensível a qual pode ser usada também como uma diretriz para a produção de traduções." (Lefevere 234).

Após esta etapa de fundação, os anos oitenta são fundamentais para o desenvolvimento dos Estudos da Tradução, como aponta Gentzler: "o crescimento dos Estudos da Tradução como uma disciplina separada é um sucesso da década de 1980", que vai incorporando perspectivas múltiplas, nas quais se integram diversas áreas de estudo como Linguística, Literatura, Sociologia, etc. Dessa maneira, o caráter interdisciplinar inerente à tradução, uma atividade que se situa, como comenta Snell-Hornby (a), entre disciplinas, entre línguas e entre culturas, fica evidente nos Estudos da Tradução. Durante a década de oitenta, progressivamente, vão sendo incorporados à reflexão tradutológica elementos que haviam permanecido à margem: observou-se um maior protagonismo do texto meta, ou texto traduzido, assim como do receptor meta, e uma maior atenção dada aos elementos extralinguísticos como, por exemplo, o papel desempenhado pelos aspectos socioculturais. Durante esta fase, surgem diversas contribuições importantes em que a interdisciplinaridade da tradução se manifesta, como o caso das teorias funcionalistas (Teoria do Escopo de Reiss and Vermeer) ou a chamada Escola de Manipulação (Toury a; Hermans), a qual é influenciada pela Teoria dos Polissistemas, que promove o descritivismo e a historicidade no estudo das traduções literárias, é centrada no produto e nas condições sociais e ideológicas que condicionam a preparação das traduções e predispõe a noção de normas de tradução.

Graças à evolução vivenciada nas décadas precedentes, os anos noventa se constituem como a etapa de consolidação dos Estudos da Tradução. Nesta etapa, "os novos paradigmas dos anos 1980 encontraram seu verdadeiro campo de testes" (Snell-Hornby 163b). Desde então, os Estudos da Tradução se converteram em um objeto de estudo poliédrico, com enfoques muito diferentes que vão desde o linguístico e textual até os enfoques filosóficos e hermenêuticos, passando pelos cognitivos, comunicativos, socioculturais e ideológicos (Hurtado Albir 125-32b). Uma boa síntese que ilustra a 
evolução temática e cronológica da reflexão tradutológica é a que apresenta Munday (424-5), que se define pelos seguintes movimentos, entre os quais existem sobreposições:

1. Teoria da tradução linguística, incluindo análise contrastiva de línguas e a emergência do conceito central de equivalência entre fonte e texto.

2. Abordagem funcionalista da tradução da Alemanha [...]

3. Teoria dos polissistemas e outras teorias de sistemas [...]. O objetivo de muitos desses estudos é o estabelecimento de normas de tradução em diferentes questões sócio-históricas. 4. A "virada cultural" preconizada por Bassnett e Lefevere (1990) [...]. Questões de poder e ideologia e como estes são manipulados através da tradução.

5. Um interesse contínuo, inspirado pelos romancistas alemães, notadamente Schleiermacher, em questões filosóficas relativas à ética e hermenêutica literárias.

As teorias deram lugar a uma pluralidade de paradigmas (Pym) ou, dito de outra forma, teorias organizadas ao redor de conceitos centrais tomam como eixo principal a equivalência, a finalidade, a descrição, a indeterminação, a tradução cultural ou a localização. Pym defende a pluralidade de paradigmas para conscientizar sobre a existência de diferentes maneiras de abordar a tradução e como todas elas podem resultar como úteis ou estimulantes em um dado momento para o tradutor (Pym 19). Além disso, este autor mostra como as teorias têm pontos em comum sob uma metalinguagem diferente e cumprem uma função institucional coletiva porque os paradigmas funcionam em contextos profissionais e acadêmicos atuais.

Para concluir esta seção, pode-se adicionar aos paradigmas anteriores o paradigma tecnológico que parte da "revolução tecnológica” (Cronin) vivida na primeira década do século XXI e que está propiciando uma nova forma de interagir entre os profissionais da tradução. O impacto da tecnologia sobre a tradução ainda precisa ser avaliado, mas sua utilidade transcende como ferramenta infor- 
mática de apoio ao tradutor para se converter em um tipo de tradução transumana, resultado de uma sociedade globalizada que gera muitos conteúdos multilíngues e abre o caminho a novos modelos de pesquisa e trabalho profissional:

Em uma sociedade globalizada como a que vivemos hoje, que gera uma quantidade enorme de conteúdo multilíngue, a tradução se estabelece como uma atividade, uma disciplina e uma indústria, heterogênea e complexa, com espaço para abordagens e modelos de trabalhos diferentes.

Por exemplo, fluxos de trabalho de tradução colaborativa, não apenas em contextos como tradução audiovisual - fansubs -; grupos de tradução ativistas; tradução wiki ou projetos de software livre, mas também em ambientes de tradução literária e profissional - por exemplo, \& Other Stories Publishing - podem se estabelecer na categoria de tradução transumana, ou seja, processos de tradução que ocorrem por meio de redes tecnológicas e extensões que substituem ou enriquecem habilidades individuais, processos e papéis que antes eram desempenhados de maneira bastante isolada. Redes e fóruns de tradução social poderiam ser exemplos claros de como a soma das inteligências coletivas poderiam estar desencadeando a transumanização da tradução e a interação mútua entre os tradutores humanos e suas ferramentas. (Alonso and Calvo 152).

\section{Qual teoria da tradução é interessante?}

Como vimos, existem muitas teorias modernas da tradução que podem ser úteis aos tradutores. Ainda que, na sequência mostrarei alguns aspectos aproveitáveis de algumas delas, recordarei neste momento que o que nos interessa não é uma única teoria das que existem (ou um único paradigma, como diria Pym), nem tampouco "uma" teoria da tradução que dê conta de toda atividade de traduzir, pois é impossível propor uma teoria para todos os tipos de textos e pares de línguas implicados que seja minimamente aplicável; 
o que nos interessa é "a” teoria, entendida como princípios que podem guiar o trabalho do tradutor profissional e orientar o estudante de tradução em seu processo de formação. Ou seja, nos interessa a teoria como uma abstração de uma prática, com suas regras e princípios, com suas ferramentas, com sua metalinguagem, com suas estratégias, com toda a bagagem que permita traduzir e justificar nossas traduções. É isso que Argüeso denomina como uma “teoria orientada à prática" (Nida, Argüeso and Ribas 126), teoria formada a partir da observação dos procedimentos que seguem os tradutores e dos problemas que eles enfrentam, e não o contrário. Por isso, os "princípios" ou "tipos de soluções", como prefere Nida (Nida, Argüeso and Ribas 130), têm um papel fundamental na didática da tradução. Não só é necessário ensinar os estudantes a traduzir, prossegue Argüeso, como também é necessário ensiná-los a justificar e defender suas decisões no âmbito de um "mercado altamente competitivo" (Nida, Argüeso and Ribas 126). O tradutor pode acertar em uma decisão, mas deve saber explicá-la quando for questionado, evitando explicações do tipo "é que não soava bem" ou "não entenderiam" (Franco Aixelá 42b). Finalmente, a teoria ajuda o tradutor a justificar e defender suas traduções. Isto tem sido constante ao longo da história: a teoria como defesa e justificativa. Precisamos recordar que o texto de base da Tradutologia, a Carta a Pamaquio (395), é uma defesa do próprio São Jerônimo às críticas que Rufi não fez de sua tradução ao latim, de uma carta de Epifânio, bispo de Constância (Chipre), escrita em grego. Não deixa de ser sintomático que, durante os mais de vinte anos de sua tradução da Vulgata (382-405), São Jerônimo não nos legou um tratado ou uma reflexão, mais ou menos extensa, sobre os princípios que ele adotou na tradução do texto bíblico; no entanto, uma crítica a uma carta simples o levou a explicar o que ele entendia por traduzir. Dele partem aquelas palavras que são o começo da famosa dicotomia da tradução ad verbum/ad sensumy, que chegam aos nossos dias em várias formulações, passando pelo fundamental de Schleiermacher (1813) para se referir aos dois modos de traduzir: "Pela minha parte, realmente, não apenas confesso, mas proclamo a plenos 
pulmões que quando traduzo os textos gregos - que não sejam as Sagradas Escrituras (onde até a estrutura da frase é mistério) - não é palavra a palavra, mas o sentido que eu exprimo." (Tradução de Aires A. Nascimento, em São Jerônimo 61-3).

É certo que o tradutor não tem o porquê de ser um teórico da tradução e que um excesso de teoria pode ser contraproducente, uma vez que desacelera sua produção: "os tradutores sem formação são, talvez, mais rápidos e mais eficientes porque sabem menos de teorias complexas e, portanto, têm menos dúvidas e perdem menos tempo refletindo sobre questões óbvias" (Pym 18). Nesse sentido, alguns profissionais rejeitam a teoria porque não se sentem identificados com as propostas das teorias modernas, algumas das quais apresentam formulações que, por certo, ajudam pouco (inclusive desorientam) o tradutor, cujas preocupações estão relacionadas, principalmente, a aspectos de produção de textos em um ambiente profissional. Rabadán (22) observou três causas para explicar o pouco apreço que os profissionais e estudantes têm pela teoria. Segundo a autora, as três causas que provocam o desapego pela teoria seriam: a) a confusão generalizada a respeito do objeto da teoria da tradução; b) a falta de capacidade pedagógica por parte dos pesquisadores e docentes, para explicar a importância da teoria; c) a rejeição a tudo o que implique em abstração da realidade concreta por parte dos alunos de tradução. As causas se dividem entre os pesquisadores por não terem conseguido definir bem o objeto de estudo, em cuja base estão as línguas, os textos, a cultura e a comunicação; entre os professores, por não saberem mostrar a importância da teoria para a prática e, finalmente, entre os alunos, por quererem começar a traduzir o quanto antes sem refletir sobre aquilo que fazem. Na minha opinião, a rejeição mais generalizada é contra aquelas teorias que propõem modelos teóricos muito distantes da prática do dia a dia (estou pensando no paradigma indeterminista de Pym, que inclui as teorias filosóficas da tradução como a desconstrução e outros enfoques como os feministas, que deixam de lado, além das questões éticas, o trabalho diário do tradutor profissional), sem ignorar a falta de relação entre teoria e prática, que 
se constata com mais frequência do que seria desejável, nos conteúdos das disciplinas de tradução dos programas universitários. Essa rejeição não tem a ver, sempre na minha opinião, com a teoria que aqui se defende, aquela que parte da prática e a orienta, porque é um fato que todo tradutor (incluindo o que reluta à teoria) traduz a partir de uma teoria interiorizada que serve de guia, consciente ou inconsciente, na hora de traduzir. Esta teoria pode ser complementada com o que é aproveitável das teorias modernas.

Para contextualizar a relação entre a teoria e a prática da tradução, revisaremos agora o que disseram alguns teóricos. Franco Aixelá (31a) considera que não é necessário saber a teoria da tradução para traduzir bem, mas por outro lado, pensa que a teoria é necessária "para saber porque traduzimos de uma determinada maneira e dar-nos conta de que existem muitas outras maneiras possíveis". Hurtado Albir (152b) considera que os estudos teóricos alcançaram um desenvolvimento considerável, que se manifesta na conformação de diversos modelos de análise do fenômeno tradutório: modelos linguísticos, textuais, comunicativos e socioculturais, cognitivos, etc. Segundo a autora, "estes modelos estudam a tradução a partir de diversos ângulos e nos permitem conhecer a tradução em todas as suas perspectivas: como fenômeno entre línguas, como manifestação textual, como ato complexo de comunicação, como atividade cognitiva de um sujeito que requer determinadas competências, como fenômeno social relacionado com outras atividades do indivíduo, etc." De fato estes modelos servem para conhecer melhor o funcionamento da tradução como texto, como ato de comunicação e como atividade cognitiva. Suas palavras apontam para a utilidade da teoria na didática da tradução na formação de tradutores; os estudantes devem saber que se deparam com um "ato complexo de comunicação" e que necessitam de algumas competências que devem ser desenvolvidas. A própria Hurtado Albir foi desenvolvendo a noção de competência tradutória desde 1997 com seu grupo de pesquisa denominado PACTE (Proceso de Adquisición de la Competencia Traductora). A competência tradutória se define como o sistema subjacente de conhecimentos neces- 
sário para saber traduzir, incluindo um conhecimento específico, um conhecimento operacional, cinco subcompetências (bilíngue, extralinguística, de conhecimentos de tradução, instrumental e estratégica) e componentes psicofisiológicos (Massana 15-7). Pym (19), por sua vez, justifica a necessidade de os tradutores conhecerem as teorias de tradução "não só para defender suas posturas, como também porque permitem descobrir outras" e, a partir da ótica das relações entre tradutor e cliente, comenta que "quanto mais termos e ideias forem conhecidas pelo tradutor e pelo cliente, melhor poderão avaliar as possibilidades da tradução".

Vejamos agora o que opinam os tradutores. Em uma enquete realizada com cinquenta e oito tradutores (Aparicio Campos), a autora confirma que cinquenta por cento das opiniões afirmam a utilidade da teoria. Mas, o interessante desta enquete é que a grande maioria dos entrevistados considera que se deveria estudar teoria da tradução na Graduação em Tradução e Interpretação e que os próprios tradutores pensam que deveriam ter conhecimentos de teoria. Esses resultados demonstram, ao menos de maneira implícita, que a teoria fornece aspectos positivos para a prática. De fato, foi um tradutor, Valentín García Yebra, o fundador dos Estudos da Tradução na Espanha e o autor do primeiro manual de teoria da tradução, Teoría y práctica de la traducción (a), que usou em suas aulas no Instituto Universitário de Tradutores e Intérpretes da Universidade Complutense de Madrid. Toda a obra teórica de García Yebra está embasada na prática da tradução. Frases como "teoria para guiar a prática e muita prática para dar vida à teoria” (24b), "a teoria e a prática de qualquer disciplina devem ser inseparáveis" ou "a teoria sozinha é estéril mas, a prática sem teoria é rotineira e cega" (134d) são reflexos do pensamento de muitos tradutores que tiveram contato com o mundo acadêmico. Segundo García Yebra, a garantia da boa qualidade da prática está na teoria que o tradutor tem interiorizado ao traduzir: "a teoria deve ser produto da prática" (135d); o tradutor se faz, se forma e, neste processo de formação da universidade "pode e deve conduzir essa prática, consolidar suas bases” (269c). Além disso, opina que a tradução é 
um ofício que se aprende desde o momento em que ocorram algumas condições intelectuais favoráveis juntamente com a condição de dedicar-lhe tempo e atenção. Para María Teresa Gallego et al. (AA.VV. 99), “a teoria da tradução vai por trás da tradução, não pela frente", ou seja, a teoria da tradução se desenvolve a partir da prática, sendo que ensinar a teoria sem a tradução seria algo sem sentido. Até aqueles que desconfiam da teoria reconhecem como válida a que parte da prática. Não devemos esquecer que os profissionais são os que traduzem e suas traduções são os produtos do seu saber fazer, um saber que na maioria das vezes não parte das teorias acadêmicas de tradução, mas sim de seu próprio trabalho interiorizado e inconsciente, mas criativo; "quando alguém traduz, no fundo está criando sua própria teoria da tradução" (Moya 10). Da mesma forma que esses tradutores,${ }^{4}$ muitos outros não negam a utilidade da teoria e ainda a consideram inerente à atividade do tradutor, contudo, insistem que essa teoria deve se alimentar da prática e não vir imposta por especulações que, na maioria das vezes, são impossíveis de serem aplicadas.

Para entender melhor a dependência recíproca entre teoria e prática, é relevante a clássica distinção entre o saber operacional e o saber declarativo: realizar com êxito uma atividade é um conhecimento implícito ou um saber operacional e explicar no que consiste realizar com êxito uma atividade é um conhecimento explícito ou um saber declarativo. O primeiro não é condição suficiente para o segundo: pode-se saber falar corretamente uma língua e não saber explicar nossa capacidade linguística. Segundo Hurtado Albir (25b), a Tradutologia, como disciplina, é um saber sobre a tradução, o que equivale a um conhecimento declarativo;

${ }^{4}$ Convém assinalar que todos esses tradutores são tradutores literários, muitos deles formados em filologia, por isso refletem sobre a dificuldade de traduzir, fato que não é tão comum para outros tipos de tradutores. Por outro lado, a tradução de um novo livro supõe sempre um novo desafio: "um sabe traduzir um livro quando já o traduziu. Não há aprendizagem prévia.” (Peña 110). Dito isso, considero válidas, para todo tradutor, as considerações gerais aqui vertidas a respeito da utilidade da teoria.

Cad. Trad., Florianópolis, v. 39, no 3, p. 595-621, set-dez, 2019. 
por outro lado, a tradução, como prática, é um saber fazer ou um saber como, isso porque constituem um conhecimento essencialmente operacional e procedimental. Desse modo, o bom profissional seria aquele que não só traduz, mas que também sabe explicar como e por que traduz. Esta é uma tarefa que deve partir do âmbito acadêmico para formar nossos estudantes, futuros tradutores; para isso é necessário estabelecer uma ponte entre o saber prático e o saber teórico, ou seja, ensinar o implícito da atividade. Diante de uma teoria meramente prescritiva que diga como se deve traduzir, deve-se defender uma teoria descritiva que ajude a predizer e a orientar; uma teoria que se entenda como inseparável da prática do tradutor e que não seja o resultado de uma formulação apriorística, elaborada como um sistema fechado, pré-fabricado, que provoque a rejeição do tradutor profissional ou do estudante. O que interessa é uma teoria que ajude o tradutor a refletir sobre o que faz e propicie a comunicação entre o mundo acadêmico e o profissional, distanciados durante tanto tempo, ainda que com maiores pontos de contato a cada dia. Nesse sentido, uma leitura muito recomendada é Can Theory Help Translators? (2002), livro elaborado em forma de diálogo que usa as trocas de e-mails a respeito da utilidade da teoria, a partir das opiniões dos dois mundos, o acadêmico e o profissional, representados por Andrew Chesterman e Eva Wagner. Este diálogo, repleto de ideias interessantes, inicia-se com uma comparação de Chesterman (Chesterman and Wagner 3) entre a teoria da tradução e a teoria de fazer cadeiras, ambas entendidas como uma fabricação de artefatos. Para isso, deve-se saber o que é uma cadeira, que tipos de cadeiras existem, como são feitas, a quem são destinadas, etc., o que se entrelaça ao trabalho artesanal do tradutor. Nesta mesma linha se situa a comparação estabelecida por Venuti (34), no final de seu artigo, entre os tradutores e os cozinheiros: "Cozinhar exige receitas e técnicas que se baseiam em suposições do que se constitui uma boa refeição. Se os tradutores são cozinheiros, então, guiam-se por uma teoria que rege a escolha dos ingredientes, as estratégias e os efeitos. Precisam aprender o que têm a sua disposição e quais usos podem lhes dar". 
Em relação com o anterior, outra questão controversa é o debate que gira em torno da própria tradução como uma ciência ou como uma arte. Sem aprofundar muito neste assunto, parece oportuno nominar alguns pesquisadores, muitos deles tradutores, como Eugene Nida, Valentín García Yebra, Andrew Chesterman, Lawrence Venuti, Roberto Mayoral, Rosa Rabadán ou Salvador Peña, para quem a atividade de traduzir tem muito mais relação com a tecnologia do que com a ciência, sendo fundamentalmente uma arte. Por exemplo, Nida (55b) afirma:

Não resta dúvida de que a capacidade de traduzir é uma aptidão, destreza ou habilidade e, ao mesmo tempo é uma arte, especialmente a tradução literária. Mas, o procedimento de traduzir não é uma ciência no sentido técnico do termo (...) porque ao traduzir se confecciona um produto, um texto, o que significa que se trata de uma tecnologia e não de uma ciência.

A partir dessa perspectiva, a tradução poderia ser entendida como um ofício que se aprende e que segue um processo, que se inicia como aprendiz, continua como oficial e termina com a figura do mestre, aquele que ensina e facilita o caminho porque sabe traduzir e pode explicar como se traduz. ${ }^{5} \mathrm{O}$ tradutor deveria se aproximar desta concepção artesanal de seu trabalho (Peña 48).

Além disso, existem fatores que podem interferir na hora de aceitar ou não a teoria como, por exemplo, os anos de experiência do tradutor e sua formação: quanto mais experiência tem um tradutor que não tenha estudado Tradução, menos apreço costuma ter pela teoria; pelo contrário, os tradutores formados em Tradu-

\footnotetext{
${ }^{5}$ Esta classificação encontra uma correlação com o que estabelecem os enfoques cognitivistas, segundo o nível de competência tradutória: leigo, estudante avançado, profissional especializado. Esses enfoques, baseados em estudos empírico-psicológicos, estudam os processos mentais que a tradução implica e o comportamento do tradutor até alcançar a habilidade profissional.
}

Cad. Trad., Florianópolis, v. 39, no 3, p. 595-621, set-dez, 2019. 
ção costumam valorizar positivamente o estudo da teoria, apesar de terem sido reticentes à abstração em sua época de estudantes. Estes últimos reconhecerão o caráter interdisciplinar da tradução que parte do conhecimento das línguas e culturas e mantém estreitos contatos com a linguística, com a filologia, com a semiótica, com a psicolinguística, com os estudos literários, sem esquecer de todas as ferramentas de apoio com as quais conta o tradutor, como são as que o ajudam a se documentar (dicionários, obras de consulta, bases de dados) e a melhorar sua produtividade (programas de informática, memórias de tradução). Tudo isso também faz parte da teoria.

\section{Para que serve a Teoria da Tradução?}

Parece existir certo consenso sobre a utilidade da teoria que parte da observação da prática. Mas, também é necessário ter em conta que a teoria, como afirma Rabadán (23), deve partir de alguns pressupostos, como por exemplo, o que entendemos por tradução (uma entidade física e material concreta, uma relação funcional entre um texto de origem e um texto meta, um tipo de comunicação intercultural de natureza linguística) ou qual ponto de vista adotamos (o estudo do processo, do produto ou de ambos), porque isso influenciará na metodologia que sigamos.

De um ponto de vista acadêmico, a teoria constitui um componente básico da formação de tradutores. A preparação universitária se caracteriza por sua capacidade de abstrair, teorizar, formular e sistematizar regularidades de devem ter relação com a prática (esta relação se refere ao processo, como se traduz, ou ao produto, o que nos dizem as traduções). Os conteúdos teóricos permitirão aos estudantes saberem por que traduzem de determinada maneira ou de outra, além de justificar suas decisões perante os clientes. Se o tradutor não sabe explicar nem justificar suas decisões, passará uma imagem pouco profissional, perderá a confiança do cliente e, possivelmente, este não voltará a contratar os seus serviços. 
De acordo com a tradução histórica da reflexão tradutória, a teoria tem um perfil marcadamente defensivo; como disse Albert Ribas (Nida, Argüeso and Ribas 130), “o aluno (ou o tradutor, em geral) necessita mais da teoria quando precisa defender sua tradução do que na hora de realizá-la”. Não podemos esquecer que traduzir é uma atividade que pode ser realizada por qualquer pessoa que conheça línguas e que esteja submetida à interpretação; assim, é muito provável que um cliente (ou um leitor) que conheça línguas, faça sua própria tradução ou interprete uma passagem de modo diferente; diante dessa possibilidade, é fundamental saber responder profissionalmente às possíveis perguntas ou críticas. Trata-se de uma questão que afeta a comunicação em geral, incluindo a monolíngue; o problema é que o tradutor não se isenta da responsabilidade e, por isso, é necessário recorrer a princípios que justifiquem sua proposta.

Portanto, a teoria é em si uma ferramenta com múltiplas ramificações: abastece o tradutor com uma metalinguagem que eleva o nível de explicação de seu trabalho e o ajuda a nomear o que faz: é o que acontece quando usamos termos como texto de partida/texto de chegada (ou texto de origem/texto meta), para se referir ao texto do qual se traduz e, ao texto traduzido, respectivamente ${ }^{6}$ tradução literal/tradução livre (com as diferentes variantes que tiveram essa oposição tradicional do método tradutório, em função do enfoque de cada teórico $)^{7}$ e outra terminologia que se encontra no glossário final do livro de Hurtado Albir (b); a teoria proporciona também estratégias textuais, criativas e documentais nas diferentes fases do processo tradutório; ao dispor de várias estratégias podemos avaliar qual será a melhor para cada tradução, conseguindo assim

\footnotetext{
${ }^{6}$ Pode-se falar também de "língua de partida/língua de chegada" e de "cultura de partida/cultura de chegada". São termos técnicos que já supõem uma determinada concepção de tradução como um conjunto de processos que vão de um lado a outro. (Pym 14).

7 Por exemplo, "tradução evidente/ tradução encoberta” (House), “equivalência formal/equivalência dinâmica (Nida), "tradução comunicativa/tradução semântica" (Newmark), tradução documental/tradução instrumental” (Nord), "adequação/aceitabilidade” (Toury), “estrangeirização/apropriação” (Venuti).
} 
que "seja sempre resultado de uma escolha consciente e não de um impulso meramente mecânico" (Franco Aixelá 31b); neste sentido, como tarefa adicional, a teoria bem aplicada contribui para educar o cliente, que em geral considera que traduzir é uma atividade que consiste somente em passar palavras de um idioma para outro; além disso, uma boa teoria facilita o caminho e economiza o tempo do tradutor, pois agiliza o processo de tradução trazendo mais profissionalismo, permitindo que se identifique como membro de um coletivo, promovendo maior visibilidade perante a sociedade.

Entre as ferramentas analíticas procedentes das teorias contemporâneas, podemos citar algumas relevantes para a prática do tradutor. Assim:

a. os sete procedimentos de tradução do enfoque linguísticocontrastivo de Vinay e Darbelnet: modulação, calque, empréstimo, tradução literal, transposição, equivalência, adaptação; esses procedimentos, que continuam sendo utilizados até hoje ao lado de outros novos como compensação, explicitação, substituição ou criação discursiva, servem para observar as decisões do tradutor, ajudam a dar nome ao que os tradutores fazem e contribuem na criação de uma metalinguagem própria da profissão;

b. a importância dada ao receptor da tradução e sua reação diante do texto traduzido das contribuições de Nida (a), que antecipa os enfoques de caráter sociológico; entre seus conceitos, vale ressaltar a importância que se dá à atualização da mensagem em função do receptor (equivalência dinâmica) e a ideia de que pode haver várias traduções corretas de um mesmo texto;

c. os princípios da teoria interpretativa ou teoria do sentido do ESIT de Paris, que se baseiam na técnica de interpretação para estabelecer três fases no processo de tradução: compreensão, desverbalização, reformulação (entre seus representantes encontra-se Hurtado Albir a); 
d. algumas abordagens dos enfoques funcionalistas (Vermeer, Reiss, Nord), fundamentais para a tradução profissional, como o conceito de objetivo ou finalidade da tradução (o escopo), que condiciona as decisões do tradutor; o encargo da tradução e o papel do iniciador da tradução;

e. ainda, dentro do enfoque funcionalista, merecem destaque as tipologias textuais propostas por Reiss e Nord (a), importantes para o método de tradução seguido pelo tradutor, de acordo com a função dominante do texto;

f. pode se destacar da própria Nord (b) seu modelo de análise funcional que permite ter em conta, antes de traduzir, fatores extratextuais e intratextuais dos textos de origem e meta;

g. o enfoque contrastivo textual é um meio para encontrar potenciais soluções para os problemas de tradução de um tipo de texto concreto e em um par de línguas concreto; para isso, tal como indica Rabadán (28), são válidos os parâmetros de significação textual em contraste de Beaugrande e Dressler (intencionalidade, aceitabilidade, situacionalidade, informatividade, intertextualidade, coerência e coesão), aplicados à tradução;

h. o valor dado pelos Estudos Descritivos da Tradução ao contexto histórico e cultural das traduções, assim como à análise do comportamento tradutório, a partir de traduções já publicadas que permitem analisar as soluções tradutórias e estudar o que se entender por tradução em um determinado momento; com isso, a análise de traduções a partir dos métodos da linguística de corpus, que também facilitam soluções já propostas para determinados pares de línguas e tipos de texto;

i. o conceito de norma em tradução (Toury b) que deve ser entendido como padrões aceitáveis de comportamento tradutório; as normas, que Toury (b) divide em iniciais, preliminares e operacionais não são universais, nem iguais no tempo e no espaço, nem válidas para todos os pares de línguas, pois obrigam o tradutor a estar atento a todas as mudanças que 
sejam produzidas; as normas surgem como guia para orientar o comportamento tradutório e não como prescrições.

As teorias nos dão diretrizes para atuar, nos permitem aproveitar os diferentes aspectos de cada uma, mas não podem ser aplicadas ao pé da letra em sua totalidade, já que cada tradução está sujeita a diversas condições como as características do próprio texto (especialmente em tradução literária), as instruções do encargo de tradução e as condições nas quais o tradutor realiza seu trabalho. Desse modo, o processo de tradução está condicionado a fatores imprevisíveis que interferirão em seu desenvolvimento. Por exemplo, o nível de conhecimento do tradutor sobre o campo temático do texto de origem fará com que a fase de documentação ocorra em menor tempo ou até que seja desnecessária; o mesmo acontece na fase de resolução de problemas de tradução: inicialmente não será possível identificar todos, ainda que a grande maioria surgirá na própria fase de tradução e serão resolvidos quando ocorrerem os enfrentamentos. Nesse sentido, as abordagens das teorias deveriam ser entendidas como sugestões, orientações ou diretrizes que procuraremos conciliar com nossa experiência profissional.

Um aspecto da teoria pouco mencionado é que ela acompanha o tradutor na solidão de seu trabalho; mostra-lhe a diversidade da prática e que os problemas de tradução que enfrenta também foram enfrentados por outros tradutores. A partir desta perspectiva, a história da tradução ajuda o tradutor a se situar em uma tradição de dois mil anos, na qual descobrirá companheiros de viagem que o farão ver que existiram outros colegas que também passaram por experiências e problemas parecidos.

Por último, outras questões não menos importantes da teoria se referem às relações entre os profissionais e o sentimento de pertencerem a um mesmo ramo. Do ponto de vista da descrição dos grupos sociais, a teoria serve para reunir e dar maior unidade ao coletivo, o que repercute positivamente na defesa dos direitos de todos os tradutores. Em outras palavras, os conhecimentos teóricos não servem somente para racionalizar as opções tradutórias, mas 
também para potencializar a comunicação entre especialistas e profissionais, incentivando o associativismo.

Finalmente, a teoria nos permite refletir sobre o que fazemos, nos serve para mostrar outras opções de tradução, evitando a tradução rotineira, nos dota de uma metalinguagem, nos proporciona diretrizes, nos ajuda a justificar nossas decisões perante os clientes, reforça nosso sentimento de pertencimento a um grupo, nos dá segurança e, parafraseando Franco Aixelá, nos faz mais livres.

\section{Considerações finais}

Boa parte das reflexões vertidas aqui procedem dos debates feitos com meus alunos nas aulas de Tradutologia, uma disciplina que ocorre na terceira fase do curso de graduação em Tradução e Interpretação da Universidade de Granada e que pretende prover aos estudantes os conhecimentos básicos relativos ao estudo e exercício da profissão, dentro da tradição da Tradutologia. Entre uma variedade de temas tratados, que vão desde o exercício da profissão até a ética em tradução, encontra-se o das relações entre teoria e prática da tradução. A amplitude temática da disciplina se justifica por sua função explicativa em relação a uma atividade profissional que ainda necessita de uma forte conscientização de sua importância, por parte daqueles que a exercem e de sólidas razões teóricas para sua valorização profissional em nosso entorno social.

A teoria, tal como foi destacado ao longo deste trabalho, é útil para os tradutores sempre e quando não for uma teoria distante da própria atividade. A teoria que o tradutor precisa é a que leve em conta seu trabalho, questiona seus problemas e contempla soluções possíveis de serem adotadas. Uma teoria que seja descritiva e explicativa, que dê diretrizes e não limites; uma teoria que parta do estudo do que fazem os tradutores e, ao mesmo tempo, leve em conta diferentes aspectos da pesquisa acadêmica, a partir de um ponto de vista interdisciplinar: modelos, tipologias textuais, estratégias e técnicas ou análise de corpus de traduções; em suma, 
uma teoria que oriente o tradutor para que ele tenha liberdade para tomar suas próprias decisões.

Ao que pese as reticências de muitos profissionais, é possível constatar, nos dias de hoje, uma maior aproximação dos tradutores ao mundo acadêmico; cada vez são mais os tradutores que participam em atividades universitárias, compartilham suas experiências com estudantes e professores e refletem em voz alta sobre seu trabalho e têm uma visão mais ampla sobre o discurso teórico. Em contrapartida, os professores tendem a aplicar em suas aulas o método de trabalho do tradutor, reproduzindo situações que se assemelham às desenvolvidas em âmbito profissional, como, por exemplo, a gestão de projetos e encargos de tradução de textos reais, incluindo a revisão, os prazos de entrega, a elaboração de pressupostos e apresentação de notas fiscais, uso de programas informatizados e de memórias de tradução e layout de traduções.

Porém, a utilidade da teoria transcende a mera prática profissional para estender seu raio de ação à definição dos grupos sociais e dar visibilidade ao tradutor perante a sociedade. A teoria é um elemento que reforça tanto a imagem social quanto a identidade profissional e pode servir como meio de conexão entre tradutores das mais diversas especialidades, ao permitir-lhes compartilhar um discurso comum em diferentes âmbitos.

Finalmente, destacarei outro aspecto da teoria: sua vertente ética, que tem a ver com as escolhas que os tradutores fazem, mas também com a responsabilidade e com o compromisso que adquirem frente ao seu trabalho. Para isso, é necessário que o tradutor conheça as ferramentas de sua profissão e melhore suas competências e habilidades para potencializar, ao máximo, a comunicação, objetivo final de seu trabalho; em suma, que cumpra com o princípio do bom fazer profissional do qual, sem dúvida, a teoria faz parte. 


\section{Referências}

AA.VV. “Saben los pájaros de ornitología?”. Vasos Comunicantes: revista de ACE traductores 41 (2008-2009): 96-101.

Alonso, Elisa e Calvo, Elisa. "Developing a Blueprint for a Technology-mediated Approach to Translation Studies.". Meta: Journal des Traducteurs 1.60 (2015): 135-157.

Aparicio Campos, Ana. "La utilidad de la teoría de la traducción desde la perspectiva de los traductores.". Trabalho de Conclusão de Curso dirigido por Pilar Ordóñez López. Universitat Jaume (2015).

Cary, Edmond. La traduction dans le monde moderne. Genève: Georg, 1956.

Catford, John C. A Linguistic Theory of Translation: An Essay in Applied Linguistics. Oxford: Oxford University Press, 1965.

Chesterman, Andrew e Wagner, Emma. Can Theory Help Translators? Manchester: St. Jerome, 2002.

Cronin, Michael. "The Translation Crowd.". Revista Tradumàtica - Traducción i Tecnologies de la Informació i Comunicació 8 (2010). Universitat Autònoma de Barcelona. 16/03/2017. http://www.raco.cat/index.php/Tradumatica/article/ view/225900.

Fedorov, Andrei. Vvedenie v teoriju perevoda. Introducción a la teoría de la traducción. Moscou: Biblioteca filoloa, 1953.

Franco Aixelá, Javier. "Prescriptivismo y descriptivismo: objetivos de una teoría de la traducción.”. Lenguas, Literatura y Traducción. Aproximaciones teóricas. Madrid: Arrecife, 2001a.

Franco Aixelá, Javier. "La teoría os hará libres.". Vasos Comunicantes: revista de ACE traductores 43 (2012b): 31-48. 
García Yebra, Valentín. Teoría y práctica de la traducción. 2 vol. Madrid: Gredos, 1982a.

García Yebra, Valentín. En torno a la traducción. Teoría. Crítica. Historia. Madrid: Gredos, 1983b.

García Yebra, Valentín. Traducción: historia y teoría. Madrid: Gredos, 1994c.

García Yebra, Valentín. Experiencias de un traductor. Madrid: Gredos, 2006d.

Gentzler, Edwin. Contemporary Translation Theories. London: Routledge, 1993.

Hermans, Theo (ed.). The Manipulation of Literature. Studies in Literary Translation. London: CroomHelm, 1985.

Hurtado Albir, Amparo. La notion de fidelité en traduction. Paris: Didier Érudition, 1990a.

Hurtado Albir, Amparo. Traducción y Traductología. Introducción a la Traductología. Madrid: Cátedra, 2001b.

Jakobson, Roman. On Linguistic Aspects of Translation. Harvard University Press: Brower, Reuben Arthur, 1959.

Lefevere, André. “Translation Studies. The Goal of the Discipline.”. Literature and Translation. New Perspectives in Literary Studies with a Basic Bibliography of Books on Translation Studies. Louvain: Acco, 1978.

Massana Roselló, Gisela. "La adquisición de la competencia traductora portuguésespañol: un estudio en torno a los falsos amigos.". Tesis de doctorado dirigida por Amparo Hurtado Albir. UniversitatAutònoma de Barcelona, 2016.

Mounin, Georges. Les problèmes théoriques de la traduction. Paris: Gallimard, 1963. 
Moya, Virgilio. La selva de la traducción. Teorías traductológicas contemporáneas. Madrid: Cátedra, 2004.

Munday, Jeremy. Introducing Translation Studies: Theories and Applications. London: Routledge, 2016.

Nida, Eugene A. Toward a Science of Translating, with Special Reference to Principles and Procedures Involved in Bible Translating. Leiden: Brill, 1964a.

Nida, Eugene A. "El desarrollo de una teoría de la traducción." Hieronymus Complutensis: el mundo de la traducción 4-5 (1996-1997b): 55-63.

Nida, Eugene A. e Taber, Charles R. The Theory and Practice of Translation. Leiden: Brill, 1969.

Nida, Eugene e Argüeso, Antonio e Ribas, Albert. “¿Sirve para algo la teoría de la traducción? Funciones de la teoría.”. Hieronymus Complutensis: el mundo de la traducción 4-5 (1996-1997): 125-130.

Nord, Christiane. Text Analysis in Translation: Theory, Methodology, and Didactic Application of a Model of Translation-Oriented Text Analysis. Amsterdam/Atlanta: Rodopi, 1991a.

Nord, Christiane. Texto base-texto meta: un modelo funcional de análisis pre traslativo. Castelló de la Plana: Universitat Jaume I, 2012b.

Peña Martín, Salvador. En pocas palabras. Apuntes de un trujamán. Madrid: Instituto Cervantes, 2011.

Pym, Anthony. Teorías contemporáneas de la traducción. Tarragona: Intercultural StudiesGroup, 2016.

Rabadán, Rosa. "Niveles de teorización en traducción: la transición entre teoría y práctica.". Estudios sobre traducción: teoría, didáctica, profesión. Vigo: Universidade de Vigo, 2005. 
Reiss, Katharina. Textypund Übersetzugs methode: Der operative Text. Kronberg: Scriptor, 1976.

Reiss, Katharina; Vermeer, Hans J.Grundlegung einer allgemeinen Translations theorie. Tubinga: Niemeyer, 1984. [Traducción al español de Sandra García Reina y Celia Martín de León. Fundamentos para una teoría funcional de la traducción. Madrid: Akal, 1996.]

São Jerônimo. Carta a Pamáquio. Sobre os problemas da tradução. Tradução de Aires A. Nascimento. Lisboa: Edições Cosmos, 1995.

Snell-Hornby, Mary. Translation Studies: An Integrated Approach. Amsterdam: Benjamins, 1988a.

Snell-Hornby, Mary. The Turns of Translation Studies. New Paradigms or Shifting Viewpoints. Amsterdam: John Benjamins, 2006b.

Toury, Gideon. "A Rationale for Descriptive Translation Studies.".The Manipulation of Literature. Sidney: Croom \& Helm, 1985a.

Toury, Gideon. Descriptive Translation Studies and beyond. Amsterdam/ Philadelphia: John Benjamins, 1995. [Traducción al español de Rosa Rabadán y Raquel Merino, Los Estudios Descriptivos de Traducción y más allá. Metodología de la investigación en Estudios de Traducción. Madrid: Cátedra, 2004b.].

Vandepitte, Sonia. "Remapping Translation Studies: Towards a Translation Studies Ontology.”. Meta: Journal des Traducteurs 3.53 (2008): 569-588.

Vega, Miguel Ángel(ed.). Textos clásicos de teoría de la traducción. Madrid: Cátedra, 1994.

Venuti, Lawrence. “¿Será útil la teoría de la traducción para los traductores?”. Vasos Comunicantes: revista de ACE traductores 16 (2000): 126-135. 
Vinay, Jean-Paul; Darbelnet, Jean-Louis. "Stylistique comparée du français et de L'anglais.”.Méthode de traduction. Paris: Didier, 1958.

Recebido em: 05/04/2019

Aceito em: 30/06/2019

Publicado em: Setembro de 2019

Willian Henrique Cândido Moura. E-mail: willianhenry_@hotmail.com ORCID: http://orcid.org/0000-0001-5009-7638

Morgana Aparecida de Matos. E-mail: morgana_matos@hotmail.com

ORCID: http://orcid.org/0000-0001-5009-7638

Fernanda Christmann. E-mail: fe.christmann.fc@gmail.com

ORCID: http://orcid.org/0000-0003-1924-7911

Cad. Trad., Florianópolis, v. 39, n 3, p. 595-621, set-dez, 2019. 